\title{
Inheritance of Race-Specific Resistance to Mycosphaerella graminicola in Wheat
}

\author{
C. A. McCartney, A. L. Brûlé-Babel, and L. Lamari
}

Graduate student, professor, and associate professor, respectively, Department of Plant Science, University of Manitoba, Winnipeg, Canada. Accepted for publication 18 October 2001.

\begin{abstract}
McCartney, C. A., Brûlé-Babel, A. L., and Lamari, L. 2002. Inheritance of race-specific resistance to Mycosphaerella graminicola in wheat. Phytopathology 92:138-144.

Mycosphaerella graminicola causes Septoria tritici blotch of hexaploid and tetraploid wheat. The inheritance of high-level resistance to Septoria tritici blotch was studied in controlled environment experiments. Intraspecific reciprocal crosses were made between hexaploid wheat lines

genes in all cases. Salamouni had three independent resistance genes to isolate MG2, two of which also controlled resistance to isolate MG96-36. ST6 had a single resistance gene to isolate MG2 and none to isolate MG96-36. The resistance genes in Salamouni and ST6 were not allelic. Two independent genes control resistance to isolate MG2 in Coulter, one of which also controlled resistance to isolate MG96-36. These data are consistent with a gene-for-gene interaction in the wheat- $M$. graminicola pathosystem.
\end{abstract} Salamouni, ST6, Katepwa, and Erik, and the tetraploid wheat lines Coulter and 4B1149. Parental, $\mathrm{F}_{1}, \mathrm{~F}_{2}, \mathrm{~F}_{3}, \mathrm{BC}_{1} \mathrm{~F}_{1}$, and $\mathrm{BC}_{1} \mathrm{~F}_{2}$ populations were evaluated for reaction to isolates MG2 and MG96-36 of $M$. graminicola. Resistance was controlled by incompletely dominant nuclear
Additional keywords: host-pathogen interactions, major gene, qualitative inheritance, Triticum aestivum, T. turgidum subsp. durum.
Septoria tritici blotch (STB) is a major leaf disease of bread and durum wheat (Triticum aestivum and T. turgidum subsp. durum) that is found in many wheat-producing areas of the world $(3,14)$. STB is caused by the ascomycete Mycosphaerella graminicola (Fuckel) J. Schröt. in Cohn (anamorph: Septoria tritici Roberge in Desmaz.). Frequent rainfall and moderate temperatures favor the development of STB epidemics $(23,24)$. Epidemics can result in yield losses of 25 to $50 \%$, with the resulting seed being shriveled and unfit for milling $(14,17,24,33)$. Incorporating genetic resistance into wheat cultivars is an economically and environmentally sound method of controlling this disease.

An understanding of the inheritance of STB resistance is needed to design an effective breeding program. However, studies of the inheritance of host resistance have produced conflicting results. These studies have reported STB resistance to be controlled by one or two dominant or partially dominant genes $(15,20,26$, $31,32)$, two to three recessive genes $(20,32)$, or by several genes with additive and dominant gene effects $(9,25,28,29)$. Differences in the isolates of $M$. graminicola, methods of inoculation, rating scales, and environmental conditions make comparisons of these studies difficult.

Physiological specialization of $M$. graminicola has been reported by many authors $(1,4,5,8,21)$ but remains controversial. A gene-for-gene interaction has been suggested in the wheat- $M$. graminicola pathosystem based on significant cultivar-isolate interactions $(5,10,11)$. Recently, Kema et al. (13) found that avirulence in the pathogen was controlled by a single locus, which is also consistent with a gene-for-gene relationship. Despite evidence for cultivar-isolate interactions, no attempts have been made to understand the genetics of resistance in wheat to different races of M. graminicola. Western Canadian isolates of M. graminicola can be differentiated into two races based on the reaction of the

Corresponding author: A. L. Brûlé-Babel; E-mail address: ababel@ms.umanitoba.ca

Publication no. P-2001-1217-02R

(C) 2002 The American Phytopathological Society hexaploid wheat line ST6 (8). Race 1 is virulent on ST6, whereas race 2 is avirulent on ST6. The objective of this study was to determine the mode of inheritance of high level resistance derived from hexaploid wheat lines, Salamouni (University of Manitoba accession 6B359) and ST6 (cv. Estanzuela Federal), and a tetraploid cultivar, Coulter, to two races of $M$. graminicola from Manitoba.

\section{MATERIALS AND METHODS}

Population development. Intraspecific reciprocal crosses were made among the four hexaploid wheat lines and among the two tetraploid wheat lines shown in Table 1. Glassine bags were placed over emasculated wheat spikes for pollination control during crossing and to ensure complete self pollination of $F_{1}, F_{2}$, and $\mathrm{BC}_{1} \mathrm{~F}_{1}$ plants. $\mathrm{F}_{1}$ and $\mathrm{F}_{2}$ generations were produced for all crosses. $\mathrm{F}_{3}, \mathrm{BC}_{1} \mathrm{~F}_{1}$, or $\mathrm{BC}_{1} \mathrm{~F}_{2}$ generations were investigated depending on the number of genes segregating in a cross as determined by $\mathrm{F}_{2}$ data. The susceptible parent was the recurrent parent in all backcrosses.

Seeds were germinated in the dark prior to planting ( 2 days $4^{\circ} \mathrm{C}, 2$ days room temperature) to ensure uniform emergence and facilitate disease ratings. Five seedlings were planted per $15-\mathrm{cm}-$ diameter pot containing a 2:1:1 soil mix (soil/sand/peat). Plants were fertilized weekly and watered as needed. Experiments containing $\mathrm{F}_{2}$ or $\mathrm{BC}_{1} \mathrm{~F}_{1}$ populations were kept in a growth room set at $21 / 19^{\circ} \mathrm{C}$ (day/night) with a $16-\mathrm{h}$ photoperiod $\left(250 \mu \mathrm{E} \mathrm{m}^{-2} \mathrm{~s}^{-1}\right)$ prior to inoculation. Experiments containing $\mathrm{F}_{3}$ or $\mathrm{BC}_{1} \mathrm{~F}_{2}$ families were grown in a greenhouse prior to inoculation rather than in controlled environments because of space limitations in the latter. In the greenhouse, temperatures ranged from $25^{\circ} \mathrm{C}$ in the day to $18^{\circ} \mathrm{C}$ at night and supplemental lighting provided a $16-\mathrm{h}$ photoperiod $\left(260 \mu \mathrm{E} \mathrm{m}^{-2} \mathrm{~s}^{-1}\right)$.

Due to space limitations of the humidity chamber, a total of 480 plants could be evaluated for reaction to $M$. graminicola in a single inoculation. Ten parental seedlings of all six wheat lines and 4 to $10 \mathrm{~F}_{1}$ seedlings of the appropriate cross, and its recipro- 
cal, were included as inoculated controls during these inoculations. By this method, 400 to 410 seedlings of a segregating population were screened at a time. A single inoculation could test an entire $F_{2}$ population, more than one $B_{1} F_{1}$ population, $20 F_{3}$ families of 20 individuals, or $41 \mathrm{BC}_{1} \mathrm{~F}_{2}$ families of 10 individuals for reaction to a particular isolate of M. graminicola. For $\mathrm{F}_{3}$ and $\mathrm{BC}_{1} \mathrm{~F}_{2}$ family experiments, all the individuals of a particular family were challenged in a single inoculation to avoid variation between inoculations. However, different families of the same population were evaluated in different inoculations because of the space limitations stated previously. The inoculated controls verified the successful infection of the pathogen.

Inoculation. Two single-spore isolates of $M$. graminicola were used in the study, each being a representative member of the two races found in western Canada. Isolate MG96-36 was typical of race 1, and MG2 was typical of race 2 (8). Infected leaf tissue from Manitoba wheat fields was the original source of these cultures. Each isolate was derived from a single pycnidium (8). From each culture, single conidiospores were isolated from freshly inoculated yeast malt agar plates with a dissecting microscope. Inoculum was produced on yeast malt agar: $4 \mathrm{~g}$ of Difco yeast extract (Difco Laboratories, Detroit), $4 \mathrm{~g}$ of Difco malt extract, $4 \mathrm{~g}$ of sucrose (Fisher Scientific, Fair Lawn, NJ), $15 \mathrm{~g}$ of Difco agar, $250 \mathrm{mg}$ of chloramphenicol (Sigma Chemical, St. Louis), and $1,000 \mathrm{ml}$ of distilled water (6). Cultures were grown at room temperature under fluorescent lights for 7 days. Conidia were harvested by flooding cultures with sterile water and dislodging spores with a wire loop. The conidia suspension was poured through cheesecloth and adjusted to $10^{7}$ spores per ml. Twenty drops of Tween 20 (polyoxyethylene sorbitan monolaurate) were added per liter of inoculum to reduce surface tension. Seedlings at the three-leaf stage were sprayed with the spore suspension until runoff with a DeVilbis-type sprayer. Plants were incubated for 67 to $72 \mathrm{~h}$ under continuous leaf wetness provided by two ultrasonic humidifiers. Seedlings were then moved to a growth cabinet set at $21 / 19^{\circ} \mathrm{C}$ (day/night) with a $16-\mathrm{h}$ photoperiod $\left(390 \mu \mathrm{E} \mathrm{m}^{-2} \mathrm{~s}^{-1}\right)$ and relative humidity between 70 and $80 \%$.

Disease assessment. Plants were evaluated for reaction to $M$. graminicola at 17 days after inoculation. At this time, there was maximum differentiation between the reactions of resistant and susceptible checks. Seedling reactions were scored by a qualitative disease rating scale developed by Rosielle (19), which was slightly modified. The modified scale accommodated the expanded chlorotic reactions of heterozygous individuals better than the original scale, which was developed to screen inbred wheat lines in the field. The modified scale is as follows: $0=$ immune characterized by an absence of pycnidial formation, an occasional hypersensitive fleck, or no visible symptoms; 1 = highly resistant with hypersensitive flecking; 2 = resistant with small chlorotic or necrotic lesions, typically no pycnidial formation; 3 = intermediate characterized by coalescence of chlorotic or necrotic lesions normally evident toward the leaf tips and to a lesser extent elsewhere on the leaf blade, very light pycnidial formation; 4 = susceptible with moderate pycnidial formation, coalesced necrotic lesions; and $5=$ very susceptible with large, abundant pycnidia, necrotic lesions extensively coalesced.

Reaction types 0 to 3 were considered resistant, whereas reaction types 4 and 5 were considered susceptible. Reaction type 3 was considered resistant because the growth and sporulation of the pathogen were severely restricted. The leaves of these plants had very few pycnidia and limited necrosis, two disease parameters commonly utilized to evaluate disease reaction $(5,10,13)$. The chlorotic reaction of reaction type 3 was interpreted as a resistance reaction because of the similarity to the chlorotic blotches of reaction type 2. Chlorosis is recognized as a resistance reaction in other pathosystems such as the wheat-Puccinia graminis f. sp. tritici pathosystem (18). The large necrotic lesions with numerous pycnidia of reaction types 4 and 5 were considered susceptible. $\mathrm{F}_{3}$ families were classified as homozygous resistant, segregating, or homozygous susceptible based on the reactions of 20 seedlings per family. $\mathrm{BC}_{1} \mathrm{~F}_{1}$-derived $\mathrm{BC}_{1} \mathrm{~F}_{2}$ families were classified as segregating or homozygous susceptible based on 10 seedlings per family. The same $\mathrm{BC}_{1} \mathrm{~F}_{2}$ families were evaluated for reaction to both isolates at the three-leaf stage. For a given $\mathrm{BC}_{1} \mathrm{~F}_{2}$ family, 10 seedlings were inoculated with one isolate of $M$. graminicola and 10 different seedlings were inoculated with the other isolate. This allowed the investigation of the relationship between resistance genes to one isolate and the resistance genes to the other isolate. Data was tested for goodness of fit to specific genetic ratios using chi-square analysis (27). Yates correction factor was used where appropriate, and data from reciprocal crosses were tested for homogeneity prior to pooling data using a homogeneity chi-square test (27).

\section{RESULTS}

The reactions of the parental wheat lines are shown in Table 1. Salamouni had a reaction type of 0 in response to both isolates, indicated by the production of tiny flecks in response to isolates MG96-36 (Fig. 1A and G) and MG2 of M. graminicola. ST6 had a reaction type of 2 in response to inoculation with MG2, which was characterized by chlorotic blotches and no pycnidial formation (Fig. 1M). However, ST6 was rated as 5 when challenged by isolate MG96-36 (Fig. 1B). Coulter had a reaction type of 1, because it produced flecks in response to isolates MG2 (Fig. 1S) and MG96-36 that were slightly larger than the flecks of Salamouni. Katepwa, Erik, and 4B1149 were highly susceptible to both isolates and were scored as 5 .

The reactions of $F_{1}$ populations to both isolates are shown in Table 2. $F_{1}$ seedlings of all resistant/susceptible crosses had a reaction type of 3 . Such $\mathrm{F}_{1}$ seedlings had coalesced, chlorotic lesions containing few pycnidia (Fig. 1C, I, O, and U). The large chlorotic lesions these $\mathrm{F}_{1}$ seedlings produced were similar to the small chlorotic blotches on ST6 when it was inoculated with isolate MG2. These data suggested resistance is incompletely dominant because the resistant reaction of $F_{1}$ plants of resistant/susceptible crosses was not as strong as the resistant reaction of the resistant parent.

Reciprocal effects were not observed in the study allowing data from reciprocal crosses to be pooled. The $\mathrm{F}_{2}$ populations of susceptible/susceptible crosses to a specific isolate did not segregate for disease reaction (Table 3). The disease reactions of the $F_{2}$ progeny of resistant/susceptible crosses included the reaction types of the parental lines and the reaction types between that of the parents. No progeny of a resistant/susceptible cross were more resistant than the resistant parent. Reaction type 3 was frequently observed in the segregating generations of resistant/susceptible crosses, whereas reaction type 4 was relatively infrequent relative to reaction types 3 or 5 . Reaction types 2 and 3 were difficult to distinguish in resistant/susceptible $F_{2}$ populations because of the similarity of the symptoms. This was particularly true for crosses with more than one gene segregating. The homozygous resistant, segregating, and homozygous susceptible classes of $\mathrm{F}_{3}$ and $\mathrm{BC}_{1} \mathrm{~F}_{2}$ families were quite distinct. Resistance was controlled by incompletely dominant nuclear genes in all segregating crosses.

Salamouni. The reactions of parental, $\mathrm{F}_{1}$, and $\mathrm{F}_{2}$ individuals of the crosses Salamouni/ST6 and Salamouni/Katepwa to isolate MG96-36 are shown in Figure $1 \mathrm{~A}$ to $\mathrm{F}$ and $\mathrm{G}$ to $\mathrm{L}$, respectively. The high level of resistance of Salamouni was recovered in the Salamouni/ST6 and Salamouni/Katepwa $\mathrm{F}_{2}$ populations. Reaction type 3 in the $F_{1}$ and $F_{2}$ generations displayed chlorotic and necrotic lesions with very little pycnidial formation (Fig. 1C, E, I, and K). The susceptibility of ST6 and Katepwa to isolate MG9636 was also recovered in the $\mathrm{F}_{2}$ generation.

The $\mathrm{F}_{2}$ populations from crosses between Salamouni and the different susceptible wheat genotypes tested with isolate MG2 
could not be validly analyzed for goodness of fit because the number of susceptible individuals was too small (Table 3). When these crosses were backcrossed to the susceptible parent, the $\mathrm{BC}_{1} \mathrm{~F}_{1}$ segregated in a 7:1 (resistant/susceptible) ratio for reaction to MG2 (Table 4), indicating three genes independently confer resistance to isolate $\mathrm{MG} 2$. The segregation ratios in the $\mathrm{BC}_{1} \mathrm{~F}_{1}$ derived $\mathrm{BC}_{1} \mathrm{~F}_{2}$ families fit a 7:1 (segregating/homozygous susceptible) ratio when inoculated with MG2 (Table 4), which is consistent with three incompletely dominant genes, each exhibiting dominant epistasis over the other resistance genes.

When inoculated with MG96-36, $\mathrm{F}_{2}$ populations from the three Salamouni/susceptible crosses segregated in a 15:1 (resistant/ susceptible) ratio (Table 3). This indicates Salamouni has two incompletely dominant genes displaying duplicate dominant epistasis to isolate MG96-36. The segregation ratios of the $\mathrm{BC}_{1} \mathrm{~F}_{1}$ were $3: 1$ (resistant/susceptible) and the $\mathrm{BC}_{1} \mathrm{~F}_{1}$-derived $\mathrm{BC}_{1} \mathrm{~F}_{2}$ families were $3: 1$ (segregating/homozygous susceptible) with isolate MG96-36 (Table 4). This is also consistent with two independent resistance genes to isolate MG96-36.

The relationship between resistance genes to both isolates was investigated with $\mathrm{BC}_{1} \mathrm{~F}_{2}$ families, which segregated in a $6: 1: 1$ (segregating to MG2 and MG96-36/segregating to MG2, homozygous susceptible to MG96-36/homozygous susceptible to MG2 and MG96-36) ratio (Table 4). This indicates Salamouni has three resistance genes. Two of the resistance genes confer resistance to both isolates and the third gene is only effective against MG2.

ST6. The reactions of parental, $\mathrm{F}_{1}$, and $\mathrm{F}_{2}$ individuals of the cross ST6/Katepwa to isolate MG2 are shown in Figure 1M to R. Resistant and susceptible reaction types equivalent to that of the parental genotypes were observed in the $\mathrm{F}_{2}$ generation. Reaction type 3 was observed in the $F_{1}$ and $F_{2}$ generations. The chlorotic reactions of reaction types 2 and 3 were similar (Fig. $1 \mathrm{M}$ and $\mathrm{O}$ to Q). Seedlings of these reaction types restrict the production of asexual fruiting bodies of the pathogen.

$\mathrm{F}_{2}$ populations involving ST6 and a susceptible wheat genotype segregated in a 3:1 (resistant/susceptible) ratio when inoculated with isolate MG2 (Table 3), which is consistent with a single gene segregating in these crosses. This was supported by $\mathrm{F}_{2}$-derived $\mathrm{F}_{3}$ families segregating in a 1:2:1 (homozygous resistant/segregating/ homozygous susceptible) ratio (Table 3 ). The backcrosses of the $F_{1}$ to the susceptible parents segregated in a 1:1 (resistant/susceptible) ratio for reaction to isolate MG2 (Table 4). These data indicate ST6 has a single incompletely dominant gene conferring resistance to isolate MG2.

The accuracy of the disease rating scale to correctly classify $\mathrm{F}_{2}$ individuals was investigated by comparing the data of $310 \mathrm{~F}_{3}$ families of the ST6/Katepwa and ST6/Erik populations to the corresponding rating of its $\mathrm{F}_{2}$ parent. In total, $94.8 \%$ of $\mathrm{F}_{2}$ plants rated 4 or 5 were confirmed homozygous susceptible by their corresponding $\mathrm{F}_{3}$ families. In total, $96.6 \%$ of $\mathrm{F}_{2}$ plants rated 2 or 3 were confirmed homozygous resistant or heterozygous based on the reaction of their corresponding $\mathrm{F}_{3}$ families. However, only $67.1 \%$ of $\mathrm{F}_{2}$ individuals rated as 2 were homozygous resistant based on the $\mathrm{F}_{3}$ family data. Therefore, the rating scale can accurately detect homozygous susceptible individuals in these $\mathrm{F}_{2}$ populations but cannot accurately differentiate between homozygous resistant individuals and heterozygous individuals. These data support treating reaction type 3 as resistant for data analysis.

ST6 was susceptible to isolate MG96-36 and acted the same as the other susceptible parental genotypes in crosses tested for reaction to MG96-36 (Tables 3 and 4).

Coulter. Figure $1 \mathrm{~S}$ to $\mathrm{X}$ displays the reactions of parental, $\mathrm{F}_{1}$, and $F_{2}$ individuals of the cross Coulter/4B1149 to isolate MG2. The high level of resistance of Coulter was recovered in the $\mathrm{F}_{2}$ generation, as was the susceptibility of 4B1149. Reaction type 3, characterized by large chlorotic and necrotic lesions with restricted pycnidial formation, was observed in the Coulter/4B1149 $F_{1}$ and $\mathrm{F}_{2}$ generations.

The $\mathrm{F}_{2}$ population of Coulter/4B1149 tested with isolate MG2 fit a 15:1 (resistant/susceptible) ratio (Table 3), indicating two genes confer resistance to MG2 and function independently of each other. For the backcross to $4 \mathrm{~B} 1149$ tested with MG2, the $\mathrm{BC}_{1} \mathrm{~F}_{1}$ fit a 3:1 (resistant/susceptible) ratio and the $\mathrm{BC}_{1} \mathrm{~F}_{1}$-derived $\mathrm{BC}_{1} \mathrm{~F}_{2}$ families fit a 3:1 (segregating/homozygous susceptible) ratio (Table 4). This indicates that two incompletely dominant resistance genes control resistance to isolate MG2 in Coulter.

When inoculated with isolate MG96-36, the Coulter/4B1149 $\mathrm{F}_{2}$ population fit a 3:1 (resistant/susceptible) ratio (Table 3), indicating that a single gene controls resistance to isolate MG96-36. The $\mathrm{BC}_{1} \mathrm{~F}_{1}$ segregated in a $1: 1$ (resistant/susceptible) ratio (Table 4), and the $\mathrm{BC}_{1} \mathrm{~F}_{1}$-derived $\mathrm{BC}_{1} \mathrm{~F}_{2}$ families fit a $1: 1$ (segregating/ homozygous susceptible) ratio (Table 4). Therefore, one incompletely dominant gene controls resistance to MG96-36.

The relationship between the resistance genes to isolates MG2 and MG96-36 was investigated with progeny tests of the $\mathrm{BC}_{1} \mathrm{~F}_{1}$. The $\mathrm{BC}_{1} \mathrm{~F}_{1}$-derived $\mathrm{BC}_{1} \mathrm{~F}_{2}$ families segregated in a 2:1:1 (segregating to MG2 and MG96-36/segregating to MG2, homozygous susceptible to MG96-36/homozygous susceptible to MG2 and MG96-36) ratio (Table 4). This indicates that a single gene confers resistance to both isolates MG96-36 and MG2, and a second gene confers resistance specific to isolate MG2 in Coulter.

Resistant/resistant. Salamouni/ST6 was evaluated for reaction to isolate MG2 to test for allelism of resistance genes in these wheat lines. The $F_{1}$ generation had a reaction type of 2 to 3 to isolate MG2 (Table 2). The $\mathrm{F}_{2}$ population of this cross segregated in reaction to isolate $\mathrm{MG} 2$ because two susceptible individuals were identified (Table 3). Poor seed set did not allow for progeny tests. However, susceptible individuals were identified in the $\mathrm{F}_{3}$ generation with available seed. Segregation in this cross indicates the three resistance genes in Salamouni cannot be allelic to the resistance gene in ST6.

TABLE 1. Reactions of parental wheat lines to isolates MG2 and MG96-36 of Mycosphaerella graminicola

\begin{tabular}{|c|c|c|c|c|c|c|c|c|c|c|c|c|c|}
\hline \multirow[b]{2}{*}{ Wheat line } & \multirow[b]{2}{*}{ Ploidy } & \multicolumn{6}{|c|}{$\mathrm{MG}^{\mathrm{a}}$} & \multicolumn{6}{|c|}{ MG96-36 } \\
\hline & & 0 & 1 & 2 & 3 & 4 & 5 & 0 & 1 & 2 & 3 & 4 & 5 \\
\hline Salamouni & Hexaploid & $330^{\mathrm{b}}$ & 0 & 0 & 0 & 0 & 0 & 170 & 0 & 0 & 0 & 0 & 0 \\
\hline ST6 & Hexaploid & 0 & 0 & 324 & 6 & 0 & 0 & 0 & 0 & 0 & 0 & 3 & 167 \\
\hline Erik & Hexaploid & 0 & 0 & 0 & 0 & 31 & 299 & 0 & 0 & 0 & 0 & 30 & 140 \\
\hline Coulter & Tetraploid & 0 & 327 & 0 & 0 & 0 & 0 & 0 & 166 & 1 & 0 & 0 & 0 \\
\hline 4B1149 & Tetraploid & 0 & 0 & 0 & 0 & 34 & 296 & 0 & 0 & 0 & 0 & 19 & 151 \\
\hline
\end{tabular}

${ }^{\text {a }}$ Reaction types 0 to $5(0=$ immune characterized by an absence of pycnidial formation, an occasional hypersensitive fleck, or no visible symptoms; $1=$ highly resistant with hypersensitive flecking; 2 = resistant with small chlorotic or necrotic lesions, typically no pycnidial formation; $3=$ intermediate characterized by coalescence of chlorotic or necrotic lesions normally evident toward the leaf tips and to a lesser extent elsewhere on the leaf blade, very light pycnidial formation; 4 = susceptible with moderate pycnidial formation, coalesced necrotic lesions; and $5=$ very susceptible with large, abundant pycnidia, necrotic lesions extensively coalesced) in which 0 to 3 are resistant and 4 and 5 are susceptible.

${ }^{b}$ Number of individuals with corresponding reaction type. 


\section{DISCUSSION}

The inheritance of race-specific resistance to M. graminicola in bread and durum wheat has not been previously reported. The data presented in this paper indicate that the number of genes controlling resistance to $M$. graminicola is dependent on the resistance source and the isolate of $M$. graminicola used to evaluate the cross. To our knowledge, the qualitative inheritance of resistance to $M$. graminicola has not been previously reported in $T$. turgidum subsp. durum. The present results are consistent with previous findings of qualitative inheritance of resistance to STB in T. aestivum $(15,20,26,31,32)$. Other authors have reported STB resistance as a quantitative trait in bread and durum wheats $(9,25$, $28,29)$. Differing reports on the mode of inheritance of STB resistance are likely due to different resistance sources and disease assessment methods in these studies. In addition, some of the previous genetic studies may have been confounded by natural inoculum in field experiments or by the utilization of isolate mixtures as the inoculum to screen segregating populations. The results of this study illustrate this problem because both of the races of M. graminicola are common in western Canada (8).

The reaction types of the resistant parental wheat lines were between 0 to 2 in this study. However, the number of resistance genes in the host did not affect the degree of resistance expressed. Coulter displayed reaction types of 1 to isolates MG2 and MG96-36, even though Coulter has two resistance genes to isolate MG2 and only one to MG96-36. Likewise, Salamouni displayed reaction types of 0 to both isolates despite Salamouni having three resistance genes to isolate MG2 and two genes to MG96-36. The degree of resistance expressed is likely due to the resistance gene involved in the incompatible interaction, the genetic background in which the gene is present, or a combination of both.
$F_{1}$ plants of resistant/susceptible crosses displayed reaction type 3 and the resistant/resistant cross had a reaction type of 2 to 3 . Reaction type 3 appears to be associated with heterozygous individuals, because the number of genetic loci conferring resistance does not appear to affect reaction type as discussed previously. Utilizing doubled haploid (DH) or recombinant inbred line (RIL) populations could simplify disease scoring in subsequent genetic studies of STB resistance in wheat. Because these populations consist of only homozygous individuals, they should be easy to score for disease reaction. If creating DH or RIL populations is impractical, $F_{1}$ plants should be included as inoculated controls when screening segregating populations with heterozygous individuals, particularly $\mathrm{F}_{2}$ and $\mathrm{BC}_{1} \mathrm{~F}_{1}$ populations. $\mathrm{F}_{1}$ plants may not be needed as controls when conducting progeny tests, such as $\mathrm{F}_{3}$ families. The reaction of an $\mathrm{F}_{3}$ family is based on a group of plants, making scoring easier than using single $\mathrm{F}_{2}$ individuals.

Kema and van Silfhout (12) found significant differences in the reactions of wheat lines at seedling and adult plant stages to two of three M. graminicola isolates, indicating differential expression of resistance at the seedling and adult plant stages. However, other studies have found good correlation between seedling and adult plant reactions $(4,30)$. Somasco et al. (26) reported that the resistance gene $S t b 4$ is likely active at all plant stages because of high positive correlation between seedling and adult plant disease scores. Segregating populations were not evaluated at the adult plant stage in this study. However, the reactions of Salamouni, ST6, Erik, Coulter, and 4B1149 (Katepwa was not investigated) to isolates MG96-36 and MG96-W were the same at seedling and adult stages (8). Isolate MG2 was not investigated at the adult plant stage, however MG96-W and MG2 both belong to race 2 and were isolated from Manitoba fields. These data suggest that the resistance genes identified in this study may be effective at both plant stages.

TABLE 2. Reactions of $\mathrm{F}_{1}$ populations to isolates MG2 and MG96-36 of Mycosphaerella graminicola

\begin{tabular}{|c|c|c|c|c|c|c|c|c|c|c|c|c|}
\hline \multirow[b]{2}{*}{ Cross $^{\mathrm{a}}$} & \multicolumn{6}{|c|}{$\mathrm{MG}^{\mathrm{b}}$} & \multicolumn{6}{|c|}{ MG96-36 } \\
\hline & 0 & 1 & 2 & 3 & 4 & 5 & 0 & 1 & 2 & 3 & 4 & 5 \\
\hline Salamouni/ST6 & $0^{\mathrm{c}}$ & 0 & 34 & 16 & 0 & 0 & 0 & 0 & 0 & 40 & 0 & 0 \\
\hline Salamouni/Katepwa & 0 & 0 & 0 & 60 & 0 & 0 & 0 & 0 & 0 & 59 & 0 & 0 \\
\hline Salamouni/Erik & 0 & 0 & 0 & 58 & 0 & 0 & 0 & 0 & 0 & 60 & 0 & 0 \\
\hline ST6/Katepwa & 0 & 0 & 0 & 119 & 0 & 0 & 0 & 0 & 0 & 0 & 0 & 20 \\
\hline ST6/Erik & 0 & 0 & 0 & 88 & 0 & 0 & 0 & 0 & 0 & 0 & 0 & 20 \\
\hline Katepwa/Erik & 0 & 0 & 0 & 0 & 8 & 32 & 0 & 0 & 0 & 0 & 0 & 40 \\
\hline Coulter/4B1149 & 0 & 0 & 1 & 15 & 0 & 0 & 0 & 0 & 0 & 24 & 0 & 0 \\
\hline
\end{tabular}

a Pooled data of reciprocal crosses.

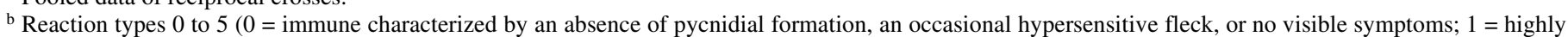
resistant with hypersensitive flecking; 2 = resistant with small chlorotic or necrotic lesions, typically no pycnidial formation; $3=$ intermediate characterized by coalescence of chlorotic or necrotic lesions normally evident toward the leaf tips and to a lesser extent elsewhere on the leaf blade, very light pycnidial formation; 4 = susceptible with moderate pycnidial formation, coalesced necrotic lesions; and $5=$ very susceptible with large, abundant pycnidia, necrotic lesions extensively coalesced) in which 0 to 3 are resistant and 4 and 5 are susceptible.

c Number of individuals with corresponding reaction type.

TABLE 3. Segregation of $\mathrm{F}_{2}$ populations and $\mathrm{F}_{2}$-derived $\mathrm{F}_{3}$ families for reaction to isolates MG2 and MG96-36 of Mycosphaerella graminicola

\begin{tabular}{|c|c|c|c|c|c|c|c|}
\hline \multirow[b]{2}{*}{ Cross $^{\mathrm{a}}$} & \multirow[b]{2}{*}{ Generation } & \multicolumn{3}{|c|}{ MG2 } & \multicolumn{3}{|c|}{ MG96-36 } \\
\hline & & Observed $^{\mathrm{b}}$ & Expected ratio & $\chi^{2}(P)^{\mathrm{c}}$ & Observed $^{\mathrm{b}}$ & Expected ratio & $\chi^{2}(P)^{\mathrm{c}}$ \\
\hline Salamouni/ST6 & $\mathrm{F}_{2}$ & $798: 2$ & $\ldots$ & $\ldots$ & $373: 24$ & $15: 1$ & $0.004(0.95)$ \\
\hline Salamouni/Katepwa & $\mathrm{F}_{2}$ & $399: 1$ & $\ldots$ & $\ldots$ & $380: 19$ & $15: 1$ & $1.26(0.26)$ \\
\hline Salamouni/Erik & $\mathrm{F}_{2}$ & $395: 4$ & $\ldots$ & $\ldots$ & $379: 21$ & $15: 1$ & $0.52(0.47)$ \\
\hline ST6/Katepwa & $\mathrm{F}_{2}$ & $297: 103$ & $3: 1$ & $0.08(0.77)$ & $0: 399$ & $0: 1$ & $\ldots$ \\
\hline ST6/Katepwa & $\mathrm{F}_{3}$ & $42: 102: 56$ & $1: 2: 1$ & $2.04(0.36)$ & $\ldots$ & $\ldots$ & $\ldots$ \\
\hline ST6/Erik & $\mathrm{F}_{2}$ & $302: 97$ & $3: 1$ & $0.07(0.79)$ & $0: 400$ & $0: 1$ & $\ldots$ \\
\hline ST6/Erik & $\mathrm{F}_{3}$ & $28: 57: 25$ & $1: 2: 1$ & $0.31(0.86)$ & $\ldots$ & $\ldots$ & $\ldots$ \\
\hline Katepwa/Erik & $\mathrm{F}_{2}$ & $0: 400$ & $0: 1$ & $\ldots$ & $0: 400$ & $0: 1$ & $\ldots$ \\
\hline Coulter/4B1149 & $\mathrm{F}_{2}$ & $356: 27$ & $15: 1$ & $0.29(0.59)$ & $291: 88$ & $3: 1$ & $0.55(0.46)$ \\
\hline
\end{tabular}

a Pooled data of reciprocal crosses.

${ }^{\mathrm{b}}$ Resistant/susceptible for $\mathrm{F}_{2}$ data; homozygous resistant/segregating/homozygous susceptible for $\mathrm{F}_{3}$ data.

${ }^{c} \chi^{2}$ corrected with Yates correction factor where appropriate. A fit to the expected ratio is accepted if $P>0.05$. 

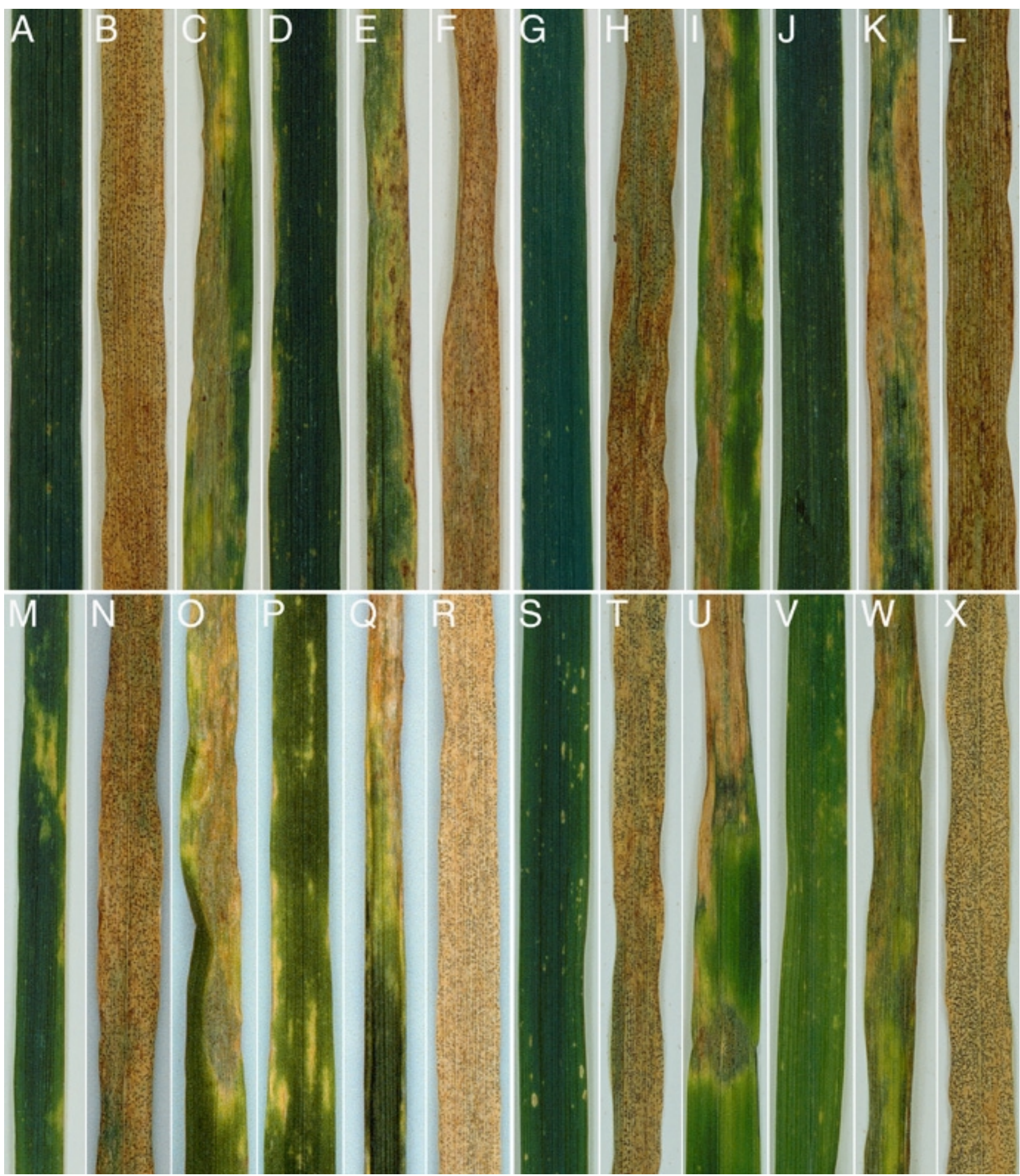

Fig. 1. Reactions of different populations to isolate MG2 or MG96-36 of Mycosphaerella graminicola. A to F, Reaction of individuals in the Salamouni/ST6 population to isolate MG96-36. A, Reaction type $0(0=$ immune characterized by an absence of pycnidial formation, an occasional hypersensitive fleck, or no visible symptoms) of Salamouni. B, Reaction type 5 ( 5 = very susceptible with large, abundant pycnidia, necrotic lesions extensively coalesced) of ST6. C, Reaction type 3 ( 3 = intermediate characterized by coalescence of chlorotic or necrotic lesions normally evident toward the leaf tips and to a lesser extent elsewhere on the leaf blade, very light pycnidial formation) of Salamouni/ST6 $\mathrm{F}_{1}$. D, E, and F, Reaction types 1,3 , and 5 of Salamouni/ST6 $\mathrm{F}_{2}$ individuals, respectively. G to $\mathbf{L}$, Reaction of individuals in the Salamouni/Katepwa population to isolate MG96-36. G, Reaction type 0 of Salamouni. H, Reaction type 5 of Katepwa. I, Reaction type 3 of Salamouni/Katepwa $F_{1} . \mathbf{J}, \mathbf{K}$, and $\mathbf{L}$, Reaction types 0,3 , and 5 of Salamouni/Katepwa $F_{2}$ individuals, respectively. $\mathbf{M}$ to $\mathbf{R}$, Reaction of individuals in the ST6/Katepwa population to isolate MG2. M, Reaction type 2 ( 2 = resistant with small chlorotic or necrotic lesions, typically no pycnidial formation) of ST6. N, Reaction type 5 of Katepwa. O, Reaction type 3 of ST6/Katepwa $F_{1}$. P, $\mathbf{Q}$, and R, Reaction types 2, 3, and 5 of ST6/Katepwa $\mathrm{F}_{2}$ individuals, respectively. $\mathbf{S}$ to $\mathbf{X}$, Reaction of individuals in the Coulter/4B1149 population to isolate MG2. S, Reaction type $1(1=$ highly resistant with hypersensitive flecking) of Coulter. T, Reaction type 5 of 4B1149. U, Reaction type 3 of Coulter/4B1149 $\mathrm{F}_{1}$. V, W, and X, Reaction types 1,3 , and 5 of Coulter/4B1149 $\mathrm{F}_{2}$ individuals, respectively. 
TABLE 4. Segregation of $\mathrm{BC}_{1} \mathrm{~F}_{1}$ populations and $\mathrm{BC}_{1} \mathrm{~F}_{1}$-derived $\mathrm{BC}_{1} \mathrm{~F}_{2}$ families for reaction to isolates $\mathrm{MG} 2$ and MG96-36 of Mycosphaerella graminicola

\begin{tabular}{|c|c|c|c|c|c|c|c|c|c|c|}
\hline \multirow[b]{2}{*}{ Cross $^{\mathrm{a}}$} & \multirow[b]{2}{*}{ Generation } & \multicolumn{3}{|c|}{ MG2 } & \multicolumn{3}{|c|}{ MG96-36 } & \multicolumn{3}{|c|}{ MG2 and MG96-36 } \\
\hline & & Observed $^{\mathrm{b}}$ & $\begin{array}{l}\text { Expected } \\
\text { ratio }\end{array}$ & $\chi^{2}(P)^{\mathrm{c}}$ & Observed $^{\mathrm{b}}$ & $\begin{array}{l}\text { Expected } \\
\text { ratio }\end{array}$ & $\chi^{2}(P)^{\mathrm{c}}$ & Observed $^{\mathrm{b}}$ & $\begin{array}{l}\text { Expected } \\
\text { ratio }\end{array}$ & $\chi^{2}(P)^{\mathrm{c}}$ \\
\hline Salamouni/ST6//ST6 & $\mathrm{BC}_{1} \mathrm{~F}_{1}$ & & & & $151: 49$ & $3: 1$ & $0.01(0.93)$ & .. & ... & $\ldots$ \\
\hline Salamouni/Katepwa//Katepwa & $\mathrm{BC}_{1} \mathrm{~F}_{2}$ & $68: 14$ & $7: 1$ & $1.18(0.28)$ & $58: 24$ & $3: 1$ & $0.59(0.44)$ & $58: 10: 14$ & $6: 1: 1$ & $1.58(0.45)$ \\
\hline Salamouni/Erik//Erik & $\mathrm{BC}_{1} \mathrm{~F}_{1}$ & $171: 25$ & $7: 1$ & $0.00(1.00)$ & $74: 22$ & $3: 1$ & $0.13(0.72)$ & & & \\
\hline Salamouni/Erik//Erik & $\mathrm{BC}_{1} \mathrm{~F}_{2}$ & $75: 7$ & $7: 1$ & $0.84(0.36)$ & $60: 22$ & $3: 1$ & $0.07(0.80)$ & $60: 15: 7$ & $6: 1: 1$ & $3.27(0.20)$ \\
\hline Coulter/4B1149//4B & $\mathrm{BC}_{1} \mathrm{~F}_{1}$ & $54: 23$ & $3: 1$ & $0.73(0.39)$ & $36: 33$ & $1: 1$ & $0.06(0.81)$ & & & . \\
\hline Coulter/4B1149//4B1149 & $\mathrm{BC}_{1} \mathrm{~F}_{2}$ & $35: 17$ & $3: 1$ & $1.26(0.26)$ & $28: 24$ & $1: 1$ & $0.17(0.68)$ & 28:7:17 & $2: 1: 1$ & $4.15(0.13)$ \\
\hline
\end{tabular}

a Pooled data of reciprocal crosses.

${ }^{\mathrm{b}}$ Resistant/susceptible for $\mathrm{BC}_{1} \mathrm{~F}_{1}$ data; segregating/homozygous susceptible for $\mathrm{BC}_{1} \mathrm{~F}_{2}$ data with two classes; and segregating to MG2 and MG9636/segregating to MG2, homozygous susceptible to MG96-36/homozygous susceptible to MG2 and MG96-36 for $\mathrm{BC}_{1} \mathrm{~F}_{2}$ data with three classes.

${ }^{c} \chi^{2}$ corrected with Yates correction factor where appropriate. A fit to the expected ratio is accepted if $P>0.05$.

The present results are consistent with physiological specialization of M. graminicola and a gene-for-gene interaction in the wheat $-M$. graminicola pathosystem. In gene-for-gene systems, only a single incompatible interaction is required to provide the host resistance to the pathogen. The present data indicate that only a single resistance gene is needed to confer resistance to the host. Each resistance gene exhibited dominant epistasis over the other resistance genes effective against a particular isolate. In addition, in gene-for-gene systems, resistance genes are race-specific due to the presence or absence of avirulence genes in different races of the pathogen. In this study, three of the six resistance genes were effective against only one of the two races identified in Manitoba. The resistant/resistant cross, Salamouni/ST6, segregated for disease reaction, which can also be observed in gene-for-gene systems. Additionally, data from other authors are consistent with a gene-for-gene interaction. Kema et al. (13) demonstrated that avirulence is controlled by a single genetic locus in M. graminicola by crossing virulent and avirulent isolates. Changes in the virulence of field populations of $M$. graminicola have also been reported. The breakdown of resistance has occurred in cvs. Florence-Aurore in Israel (4) and Heron and Robin in Australia (1). Conversely, Etit 38 became resistant to field isolates after it was no longer commonly grown in Israel (4).

A solid understanding of host-pathogen interactions is critical to design an efficient breeding program for disease resistance. Incorporating the ST6 resistance gene into a Canadian variety would not provide effective resistance because a portion of the pathogen population is virulent on ST6 (8). Further efforts need to be taken to develop a differential set of wheat lines to survey $M$. graminicola populations for avirulence/virulence genes. This will allow wheat breeders to select appropriate resistance genes based on the avirulence/virulence genes present in the local M. graminicola population. The construction of a differential set will require genetic studies to elucidate the relationships between different resistance sources. Wilson (32) identified three unlinked loci for STB resistance in hexaploid wheat, $S t b 1, S t b 2$, and $S t b 3$. A fourth gene, Stb4, has been proposed (26) based on independent assortment with $S t b 1$, but its relationship with $S t b 2$ and $S t b 3$ is unknown. Efforts need to be taken to determine the relationship between these resistance genes and the four unlinked genes among Salamouni and ST6. The relationship between the resistance genes in T. aestivum and T. turgidum subsp. durum is also unknown.

Genetic studies of avirulence in the pathogen will be useful in understanding the interactions in the wheat- $M$. graminicola pathosystem. Kema et al. (13) reported that avirulence segregated as a single locus when evaluated on resistant lines Shafir, Kavkaz, and Veranopolis. More research is needed to determine whether all avirulence genes are located at this locus or if they are scattered throughout the genome. This is important because sexual recombination of $M$. graminicola commonly occurs in the United States (16) and the sexual state has been identified on different continents $(2,7,22)$. The development of new races through sexual recombination may be hindered if avirulence genes are linked, thereby prolonging the effectiveness of resistance genes.

The results of this study indicate that resistance to $M$. graminicola is qualitative in the bread and durum wheat resistance sources tested. Resistance was controlled by incompletely dominant genes, each exhibiting dominant epistasis over the other resistance genes. The number of resistance genes segregating in a cross depended on the resistance source and the race used to test for reaction to $M$. graminicola. Race-specific resistance genes were identified in this study. This is consistent with a gene-forgene system.

\section{ACKNOWLEDGMENTS}

We thank the Natural Sciences and Engineering Research Council of Canada, Western Grains Research Foundation, Agriculture and Agri-Food Canada, and the Canadian Wheat Board for their financial support.

\section{LITERATURE CITED}

1. Ballantyne, B., and Thomson, F. 1995. Pathogenic variation in Australian isolates of Mycosphaerella graminicola. Aust. J. Agric. Res. 46:921-934.

2. Brown, J. S., Kellock, A. W., and Paddick, R. G. 1978. Distribution and dissemination of Mycosphaerella graminicola (Fuckel) Schroeter in relation to the epidemiology of speckled leaf blotch of wheat. Aust. J. Agric. Res. 29:1139-1145.

3. Eyal, Z. 1981. Integrated control of septoria diseases of wheat. Plant Dis. 65:763-768.

4. Eyal, Z., Amiri, Z., and Wahl, I. 1973. Physiological specialization of Septoria tritici. Phytopathology 63:1087-1091.

5. Eyal, Z., Scharen, A. L., Huffman, M. D., and Prescott, J. M. 1985. Global insights into virulence frequencies of Mycosphaerella graminicola. Phytopathology 75:1456-1462.

6. Eyal, Z., Scharen, A. L., Prescott, J. M., and van Ginkel, M. 1987. The Septoria diseases of wheat: Concepts and methods of disease management. International Maize and Wheat Improvement Center, Mexico, D.F.

7. Garcia, C., and Marshall, D. 1992. Observations on the ascogenous stage of Septoria tritici in Texas. Mycol. Res. 96:65-70.

8. Grieger, A. P. 2001. Host-pathogen interactions in the wheat-Mycosphaerella graminicola pathosystem. M.S. thesis. University of Manitoba, Winnipeg, Manitoba, Canada.

9. Jlibene, M., Gustafson, J. P., and Rajaram, S. 1994. Inheritance of resistance to Mycosphaerella graminicola in hexaploid wheat. Plant Breed. 112:301-310.

10. Kema, G. H. J., Annone, J. G., Sayoud, R., Van Silfhout, C. H., Van Ginkel, M., and de Bree, J. 1996. Genetic variation for virulence and resistance in the wheat-Mycosphaerella graminicola pathosystem. I. Interactions between pathogen isolates and host cultivars. Phytopathology $86: 200-212$.

11. Kema, G. H. J., Sayoud, R., Annone, J. G., and Van Silfhout, C. H. 1996. 
Genetic variation for virulence and resistance in the wheat-Mycosphaerella graminicola pathosystem. II. Analysis of interactions between pathogen isolates and host cultivars. Phytopathology 86:213-220.

12. Kema, G. H. J., and van Silfhout, C. H. 1997. Genetic variation for virulence and resistance in the wheat-Mycosphaerella graminicola pathosystem. III. Comparative seedling and adult plant experiments. Phytopathology 87:266-272.

13. Kema, G. H. J., Verstappen, E. C. P., and Waalwijk, C. 2000. Avirulence in the wheat Septoria tritici leaf blotch fungus Mycosphaerella graminicola is controlled by a single locus. Mol. Plant-Microbe Interact. 13:1375-1379.

14. King, J. E., Cook, R. J., and Melville, S. C. 1983. A review of Septoria diseases of wheat and barley. Ann. Appl. Biol. 103:345-373.

15. Lee, T. S., and Gough, F. J. 1984. Inheritance of Septoria leaf blotch ( $S$. tritici) and Pyrenophora tan spot (P. tritici-repentis) resistance in Triticum aestivum cv. Carifen 12. Plant Dis. 68:848-851.

16. McDonald, B. A., Pettway, R. E., Chen, R. S., Boeger, J. M., and Martinez, J. P. 1995. The population genetics of Septoria tritici (teleomorph Mycosphaerella graminicola). Can. J. Bot. 73(suppl.):S292-S301.

17. McKendry, A. L., Henke, G. E., and Finney, P. L. 1995. Effects of septoria leaf blotch on soft red winter wheat milling and baking quality. Cereal Chem. 72:142-146.

18. Roelfs, A. P., and Martens, J. W. 1988. An international system of nomenclature for Puccinia graminis f. sp. tritici. Phytopathology 78:526533.

19. Rosielle, A. A. 1972. Sources of resistance in wheat to speckled leaf blotch caused by Septoria tritici. Euphytica 21:152-161.

20. Rosielle, A. A., and Brown, A. G. P. 1979. Inheritance, heritability and breeding behaviour of three sources of resistance to Septoria tritici in wheat. Euphytica 28:385-392.

21. Saadaoui, E. M. 1987. Physiological specialization of Septoria tritici in Morocco. Plant Dis. 71:153-155.
22. Scott, P. R., Sanderson, F. R., and Benedikz, P. W. 1988. Occurrence of Mycosphaerella graminicola, teleomorph of Septoria tritici, on wheat debris in the UK. Plant Pathol. 37:285-290.

23. Shaner, G., and Finney, R. E. 1976. Weather and epidemics of Septoria leaf blotch of wheat. Phytopathology 66:781-785.

24. Shipton, W. A., Boyd, W. R. J., Rosielle, A. A., and Shearer, B. I. 1971. The common Septoria diseases of wheat. Bot. Rev. 37:231-262.

25. Simon, M. R., and Cordo, C. A. 1998. Diallel analysis of four resistance components to Septoria tritici in six crosses of wheat (Triticum aestivum). Plant Breed. 117:123-126.

26. Somasco, O. A., Qualset, C. O., and Gilchrist, D. G. 1996. Single-gene resistance to Septoria tritici blotch in the spring wheat cultivar Tadinia. Plant Breed. 115:261-267.

27. Strickberger, M. W. 1985. Genetics. 3rd ed. Macmillan Publishing Company, New York.

28. van Ginkel, M., and Scharen, A. L. 1987. Generation mean analysis and heritabilities of resistance to Septoria tritici in durum wheat. Phytopathology 77:1629-1633.

29. van Ginkel, M., and Scharen, A. L. 1988. Diallel analysis of resistance to Septoria tritici isolates in durum wheat. Euphytica 38:31-37.

30. Wainshilbaum, S. J., and Lipps, P. E. 1991. Effect of temperature and growth stage of wheat on development of leaf and glume blotch caused by Septoria tritici and S. nodorum. Plant Dis. 75:993-998.

31. Wilson, R. E. 1979. Resistance to Septoria tritici in two wheat cultivars, determined by independent single dominant genes. Australas. Plant Pathol. 8:16-18.

32. Wilson, R. E. 1985. Inheritance of resistance to Septoria tritici in wheat. Pages 33-35 in: Septoria of Cereals: Proceedings of the Workshop. A. L. Scharen, ed. Montana State University, Bozeman.

33. Ziv, O., and Eyal, Z. 1978. Assessment of yield component losses caused in plants of spring wheat cultivars by selected isolates of Septoria tritici. Phytopathology 68:791-796. 